\title{
Colaboração unilateral premiada como consectário lógico das balizas constitucionais do devido processo legal brasileiro
}

\author{
Unilateral plea bargain as a logical result of the brazilian due \\ process's constitucional guidelines
}

Marcos Paulo Dutra Santos ${ }^{1}$

Professor da EMERJ, FESUDEPERJ e AMPERJ - Rio de Janeiro/RJ marcospdutra@uol.com.br

http://lattes.cnpq.br/8149938872041422

http://orcid.org/0000-0003-3405-2047

\begin{abstract}
Resumo: O artigo objetiva assentar a possibilidade da colaboração premiada unilateral, independentemente de acordo prévio com o Ministério Público. A partir do contraponto entre os modelos norte-americano e italiano de justiça penal negocial e o praticado no Brasil, demonstrar-se-á que a aceitação dessa modalidade de cooperação, considerada a natureza dos benefícios previstos em lei, é decorrência natural e inafastável dos princípios constitucionais informativos do ordenamento processual penal brasileiro.
\end{abstract}

Palavras-chave: Colaboração Premiada Unilateral; Controle jurisdicional; Ministério Público.

ABSTRACT: This article analyzes the possibility of an unilateral plea bargain, not depending on a previous agreement with the prosecution. From the comparative study between the American and Italian bargained criminal justice and the one practiced in Brazil, it reveals the acceptance of this type of cooperation,

1 Mestre em Direito Processual pela UERJ, Defensor Público do Estado do Rio de Janeiro, Assessor de Ministro do STF (2015/2016), Professor de Processo Penal e de Execução Penal da Escola da Magistratura do Estado do Rio de Janeiro (EMERJ), da Fundação Escola da Defensoria Pública do Estado do Rio de Janeiro (FESUDEPERJ), da Escola de Direito da Associação do Ministério Público do Estado do Rio de Janeiro (AMPERJ), e dos Cursos Fórum/RJ e Supremo/BH. 
according to the nature of the benefits involved, as a natural and inevitable consequence of the constitutional principles that guide Brazilian Criminal Procedure Law.

KeYwords: Unilateral plea bargain; Judicial control; Prosecution.

SUMÁRIO: Introdução; 1. Colaboração Premiada nos Estados Unidos da América; 2. Colaboração Premiada na Itália; 3. Colaboração Premiada no Brasil; 4. Cooperação Unilateral Premiada; Considerações Finais; Referências Bibliográficas.

\section{INTRODUÇÃO}

A justiça penal negociada, fenômeno verificado primordialmente nos ordenamentos regidos pela common law, sobretudo o norte -americano, foi introduzido no Brasil na década de 1990 e, desde então, tem se espraiado significativamente, mas por dois caminhos distintos.

O primeiro, despenalizador, que tem na Lei $n^{\circ} 9.099$, de 26 de setembro de 1995, com as modificações introduzidas pela Lei n ${ }^{0} 11.313$, de 28 de junho de 2006, o diploma legal central, consideradas a composição civil, a transação penal, a exigência de representação para os delitos de lesão corporal leve e culposa e a suspensão condicional do processo, ex vi dos artigos 74, parágrafo único, 76, 88 e 89, respectivamente. Voltam-se para as infrações de menor potencial ofensivo - contravenções penais e crimes apenados até dois anos ${ }^{2}$, independentemen-

2 Excepcionalmente, por expressa disposição legal, alcançam infrações penais cuja reprimenda máxima supera 2 anos de prisão, como a lesão corporal culposa de trânsito, tanto na forma simples quanto circunstanciada, haja vista o preceituado no $\S 1^{\circ}$ do artigo 291 da Lei ${ }^{\circ} 9.503$, de 23 de setembro de 1.997 (Código de Trânsito Brasileiro), acrescido pela Lei no 11.705 , de 19 de junho de 2.008, consoante jurisprudência pacífica do Superior Tribunal de Justiça, admitindo, por exemplo, a renúncia ao direito de representação, e consequente extinção da punibilidade, mesmo quando presente a causa de aumento de pena relativa à ausência de habilitação para condução de veículo automotor - 5a Turma, HC 25.082/SP, Rel. Min. Laurita Vaz, j. em 18/03/2004, DJ 12/04/2004, p. 222; 6 ${ }^{\mathrm{a}}$ Turma, HC 299.223/RJ, Rel. Min. Nefi Cordeiro, j. em 24/05/2016, DJe 06/06/2016. 
te da cominação cumulativa ou alternativa de outras reprimendas não privativas de liberdade ${ }^{3}$ - e, no último caso (suspensão condicional do processo), também para as de média reprovabilidade, isto é, injustos cuja pena mínima não exceda um ano. Tais instrumentos legais permitem ao Ministério Público não formalizar a denúncia, apesar de presentes as condições para tanto, ou não prosseguir com a ação penal, no

3 A Lei no 11.313/06, ao modificar o conceito de infração de menor potencial ofensivo previsto na redação originária do art. 61 da Lei no $9.099 / 95$, eliminou a ressalva existente em relação aos injustos com rito especial. Ademais, embora se refira, especificamente, à irrelevância da cominação cumulativa ou alternativa da pena de multa, tal alusão foi exemplificativa, adotando, como parâmetro, o conceito de infração penal inserto no art. $1^{\circ}$ da Lei de Introdução ao Código Penal (Decreto-Lei no 3.914 , de 9 de dezembro de 1941), correspondente à toda conduta apenada isoladamente com reclusão, detenção ou prisão simples; e/ou multa. Com efeito, caso o legislador pretendesse compreender a totalidade de reprimendas listadas no ordenamento, cumulativas ou alternativas à prisão, gastaria, provavelmente, ao menos meia página na transcrição do art. 61 da Lei ${ }^{\circ} 9.099 / 95$. Mesmo antes da Lei $n^{\circ} 11.313 / 06$, ainda sob a égide do art. $2^{\circ}$, parágrafo único, da Lei ${ }^{\circ} 10.259 / 01$ (cuja definição de infração de menor potencial ofensivo predominava sobre a existente no texto original do art. 61 da Lei ${ }^{\circ}$ 9.099/95), este já era o entendimento prevalente na doutrina - v.g., GRINOVER, Ada Pellegrini Grinover et al. Juizados Especiais Criminais. $4^{\mathrm{a}}$ ed. São Paulo: RT, 2002, pp. 373-374 e 378); PRADO, Geraldo e CARVALHO, Luis Gustavo Grandinetti Castanho de. Lei dos Juizados Especiais Criminais, Comentários e Anotações. $3^{\text {a }}$ ed., Rio de Janeiro: Lumen Juris, 2003, pp. 8-9, 11-12 e 17; JESUS, Damásio E. de. Lei dos Juizados Especiais Criminais Anotada. $7^{\text {a }}$ ed. São Paulo: Saraiva, 2002, p. 19 -, circundado por Tribunais, como odo Estado do Rio de Janeiro, haja vista o enunciado $\mathrm{n}^{\circ} 2$ do Aviso $\mathrm{n}^{\circ}$ 2/2002; além do Superior Tribunal de Justiça - $5^{\mathrm{a}}$ Turma, HC $\mathrm{n}^{\circ}$ 40.207/MG, Rel. Min. José Arnaldo da Fonseca, j. em 11/10/05, v.u., DJ de 21/11/05, p. 263; HC n ${ }^{\circ} 30.405 / \mathrm{SP}$, j. em 4/11/03, DJ de $1^{\circ} / 12 / 03$, p. 00386, v.u; $3^{\text {a }}$ SEÇÃO, C.C. $\mathrm{n}^{\mathrm{o}}$ 38.940/SP, Rel. Min. Hamilton Carvalhido, j. em 26/11/03, v.u., DJ de19/12/03, p. 317; $6^{\text {a }}$ Turma, HC no 24.148/SP, j. em 10/2/04, Rel. Min. Paulo Medina, v.u. (informativo STJ no 198 ); e do Supremo Tribunal Federal $-2^{\text {a }}$ Turma, HC no 85.694/MG, Rel. Min. Ellen Gracie, j. em 7/6/05. Exemplo emblemático disso é o crime de abuso de autoridade, que, sem embargo das quatro penas cominadas cumulativamente ao infrator - multa, detenção de dez dias a seis meses, perda do cargo e inabilitação para o exercício de qualquer outra função pública pelo prazo de até três anos $\left(\operatorname{art.~} 6^{\circ}, \S 3^{\circ}\right.$, da Lei $n^{\circ} 4.898 / 65$ ) -, desafia a competência do Juizado Especial Criminal, bem como os institutos despenalizadores (composição cível dos danos e transação penal), porquanto a pena máxima em abstrato não excede dois anos. Nesse diapasão, STJ, $5^{\mathrm{a}}$ Turma, $\mathrm{HC}$ n $^{\circ} 163.282 / \mathrm{RO}$, Rel. Min. Arnaldo Esteves Lima, j. em 18/5/2010, DJe de 21/6/2010. 
caso da suspensão condicional do processo, deixando de lado o exame da pretensão punitiva estatal em prol de acordos entre o imputado e a alegada vítima ou entre o primeiro e o Parquet, relativizando os princípios da obrigatoriedade e da indisponibilidade da ação penal pública. Prioriza-se o consenso em vez de apurar o ocorrido.

O segundo rumo da justiça penal negocial, por outro lado, ostenta viés destacadamente punitivo. Nesse universo está a colaboração premiada, enquanto "veículo de produção probatória, porquanto, a partir das informações disponibilizadas, deflagram-se diligências em busca de provas que as endossem”. Persegue-se, através dela, a condenação do maior número de agentes, inclusive do cooperador, mas, em relação a este, atenuada- apenas excepcionalmente será agraciado com o perdão judicial ou, até, ministerial, consubstanciado no arquivamento do inquérito ou das peças de informação, nos moldes do $\S 4^{\circ}$ do artigo $4^{\circ}$ da Lei $\mathrm{n}^{0} 12.850$, de 2 de agosto de 2013.

A par da Lei $\mathrm{n}^{0}$ 9.807, de 13 de julho de 1999, que vem a ser o diploma legal geral da delação premiada, disciplinando-a nos artigos 13 a 15, existem oito outras hipóteses específicas: crimes hediondos (artigo $8^{\circ}$, parágrafo único, da Lei $\mathrm{n}^{\circ} 8.072$, de 25 de julho de 1990), extorsão mediante sequestro (artigo 159, §4 , do Código Penal, com a redação dada pela Lei $n^{\circ} 9.269$, de 2 de abril de 1996), crimes contra o sistema financeiro nacional (artigo $25, \S 2^{\circ}$, da Lei $\mathrm{n}^{\circ} 7.492$, de 16 de junho de 1986, com a redação dada pela Lei no 9.080, de 19 de julho de 1995), crimes contra a ordem econômica e tributária (artigo 16, parágrafo único, da Lei $\mathrm{n}^{\circ} 8.137$, de 27 de dezembro de 1990, com a redação dada pela Lei $n^{0} 9.080 / 95$ ), a atrair espécie própria de cooperação premiada, quando atrelados à formação de cartel, aplicável também aos delitos licitatórios e à associação criminosa (artigos $86 \mathrm{e}$ 87 da Lei $n^{\circ} 12.529$, de 30 de novembro de 2011), lavagem de capitais (artigo $1^{\circ}, \S 5^{\circ}$, da Lei $n^{\circ} 9.613$, de 3 de março de 1998, com a redação dada pela Lei $\mathrm{n}^{\circ} 12.683$, de 9 de julho de 2012), entorpecentes (artigo 41 da Lei $n^{0} 11.343$, de 23 de agosto de 2006) e organização criminosa (artigo $4^{\circ}$ da Lei $\mathrm{n}^{\circ} 12.850 / 13$ ).

4 SANTOS, Marcos Paulo Dutra. Colaboração (Delação) Premiada. Salvador: Jus Podivum, 2016, p. 81. 
Diferentemente dos institutos despenalizadores, destacadamente a transação penal e a suspensão condicional do processo, que repercutem no exercício da ação penal pública, a colaboração premiada, a depender da hipótese, importa perdão judicial, atuando como causa extintiva da punibilidade, ex vi do art. $4^{\circ}$, caput, da Lei $\mathrm{n}^{\mathrm{o}} 12.850 / 13$ (crime organizado), do $\S 5^{\circ}$ do art. $1^{\circ}$ da Lei $n^{\circ} 9.613 / 98$ (lavagem de dinheiro), do art. 87, caput e parágrafo único, da Lei ${ }^{\circ} 12.529 / 11$ (crimes relacionados à prática de cartel), além do art. 13 da Lei n ${ }^{0}$ 9.807/99, que é o diploma legal reitor do tema; causa de substituição da pena privativa de liberdade por restritiva de direitos, quando tiver por objeto organização criminosa ou lavagem de dinheiro; causa de fixação do regime inicial aberto ou semiaberto, também se estiver relacionada com o crime de lavagem de capitais, ou de progressão de regime, em se tratando de organização criminosa, considerado o art. $4^{\circ}, \S 5^{\circ}$, da Lei $n^{\circ} 12.850 / 2013$; causa de redução da pena, sempre na fração de um a dois terços, presente em todas as hipóteses de delação premiada, exceto a pertinente à organização criminosa, em que o redutor é de até dois terços, não garantindo de antemão qualquer fração reducional mínima - neste último caso, admite-se, ainda, a diminuição da reprimenda, em até metade, após a sentença penal condenatória, configurando incidente de execução penal, provisória ou definitiva (art. $4^{\circ}, \S 5^{\circ}$, da Lei ${ }^{\circ} 12.850 / 2013$ ).

O Pleno do Supremo Tribunal Federal ${ }^{5}$ ainda entendeu, à unanimidade, que a colaboração premiada pode atuar como causa de exclusão ou de atenuação dos efeitos da sentença penal condenatória, porquanto “(...) havendo previsão em Convenções firmadas pelo Brasil para que sejam adotadas 'as medidas adequadas para encorajar' formas de colaboração premiada (art. 26.1 da Convenção de Palermo) e para 'mitigação da pena' (art. 37.2 da Convenção de Mérida), no sentido de abrandamento das consequências do crime, o acordo de colaboração, ao estabelecer as sanções premiais a que fará jus o colaborador, pode dispor sobre questões de caráter patrimonial, como o destino de bens adquiridos com o produto da infração pelo agente colaborador (...)”.

Constata-se, portanto, que a colaboração premiada, diferentemente dos institutos despenalizadores, projeta-se na punibilidade, na

5 HC 127.483/PR, Rel. Min. Dias Toffoli, j. em 27/8/2015, DJe de 4/2/2016. 
aplicação da pena e, na dicção do Supremo, até nos efeitos secundários da condenação criminal, matérias sujeitas à reserva de jurisdição. Partindo dessa premissa, cumpre analisar ser, ou não, constitucionalmente admissível condicionar, impreterivelmente, o reconhecimento da cooperação e a consequente concessão do prêmio respectivo pelo juiz à formalização e à homologação prévias de acordo entre o imputado e o Ministério Público, mas não sem antes examinar como a questão é equacionada nas legislações norte-americana e italiana, indubitavelmente as duas que mais influência exerceram sobre o ordenamento pátrio no trato da matéria.

Igualmente cumpre elucidar se a cooperação unilateral teria vez quando o prêmio correspondesse ao não oferecimento da denúncia, previsto no art. $4^{\circ}, \S 4^{\circ}$ da Lei $n^{\circ} 12.850 / 13$.

Deve-se, ainda, estabelecer um diálogo entre a admissibilidade da colaboração premiada unilateral e a constitucionalidade da legitimação dada aos delegados de polícia para entabular acordos de cooperação, ex vi dos $\S \S 2^{\circ}$ e $6^{\circ}$ do art. $4^{\circ}$ da Lei $\mathrm{n}^{\circ} 12.850 / 13$.

Finalmente, fixada a viabilidade de se premiar a colaboração unilateral, há de lhe examinar a natureza enquanto direito público subjetivo do delator, especialmente no tocante à extensão, a alcançar apenas uma ou algumas das contrapartidas legais, a ser(em) eleita(s) pelo juiz, quando da sentença, ou benesse(s) específica(s).

\section{Colaboração premiada nos Estados Unidos da AmÉrica}

Em vista do adversary system, não se concebe qualquer controle jurisdicional no tocante ao exercício da ação penal pela promotoria, notabilizado pela absoluta discricionariedade - prosecutorial discretion -, irradiada às atividades policial e jurisdicional, e mesmo à execução da pena - probation $^{6}$-, guiando-se por vetores políticos e utilitaristas: descartar os delitos irrelevantes, concentrando-se os esforços na criminalidade de vulto, cuja repressão rende visibilidade social, e, exatamen-

6 MUSSO, Rosanna Gambini. Il Processo Penale Statunitense, Soggetti ed Atti. $2^{\mathrm{a}}$ ed., Torino: G. Giappichelli, 2001. p. 32-33. 
te por isso, é a que interessa combater. Não por acaso apenas de cinco a dez por cento das demandas criminais chegam a julgamento - trial -, terminando as demais no pretrial ${ }^{7}$,a revelar ser a justiça penal norte-americana inteiramente pautada na barganha.

Não são poucas as críticas ao plea bargaining. Rubens Casara e Antonio Pedro Melchior observam, respaldados em artigo de Andrew Hessick e Reshma Saujani ${ }^{8}$, que acusados apenas reconhecem a culpabilidade para não se submeter aos riscos de uma reprimenda maior, fenômeno nomeado de "problema do inocente". Lucian E. Derwan e Vanessa A. Edkins relatam o episódio no qual John Dixon foi acusado de ter roubado e abusado sexualmente de uma jovem de 21 anos, em Nova Jersey, em 23 de dezembro de 1990. Pressionado pela Promotoria, ante a perspectiva de receber pena substancialmente maior, caso optasse pelo julgamento, declarou-se culpado, sendo condenado a 45 anos de prisão. Todavia, foi liberado 10 anos depois, por força de exame de DNA, que elidiu a autoria delitiva ${ }^{10}$. Cynthia Alkon aponta que o direito a um julgamento se torna verdadeira punição - "trial penalty" -, ensejando condenações quatro vezes superiores às oriundas da barganha ${ }^{11}$. $\mathrm{O}$ acordo fragiliza a ampla defesa, escamoteando a mediocridade técnica de certos defensores, afinal o pacto é, sempre, a alternativa mais cômoda - no embate, as deficiências técnicas viriam rapidamente à tona. Vinicius Vasconcellos aponta o quanto a justiça penal negocial tem deteriorado a relação advogado-cliente, mesmo quando bem preparado e intencionado é o profissional, elegendo opções que não necessariamen-

7 MUSSO, Rosanna Gambini. Ob. cit., p. 32-35.

8 HESSICK, Andrew; SAUJANI, Reshma. Plea Bargaining and Convicting the Innocent: the Role of the Prosecutor, the Defense Counsel and the Judge. Bringham Young University Journal of Public Law, v.16, p. 189-242, 2002.

9 CASARA, Rubens R. R.; MELCHIOR, Antonio P. Estado Pós-Democrático e Delação Premiada: Crítica ao Funcionamento Concreto da Justiça Criminal Negocial no Brasil. In: ESPIÑEIRA, Bruno; CALDEIRA, Felipe (Org.). Delação Premiada. Belo Horizonte: D’Plácido, 2016. p. 424, nota 21.

10 DERWAN; Lucian E.; EDKINS, Vanessa A. The Innocent Defendant's Dilemma: An Innovative Empirical Study of Plea Bargaining's Innocence Problem. Journal of Criminal Law and Criminology, v. 103, n. 1, mai./2012. p. 5-6.

11 ALKON, Cynthia. Plea Bargaining as a Legal Transplant: A Good Idea for Troubled Criminal Justice Systems? Transnational Law and Contemporary Problems, v. 19, abr./2010, p. 394. 
te seriam as melhores ao acusado, afastando-o “(...) de sua característica posição de resistência à pretensão punitiva estatal” ${ }^{12}$. Não raro a mídia é utilizada como forma de compelir o imputado a celebrar acordos de cooperação, especialmente por meio de vazamento de informações pelos órgãos de repressão estatal, polícia e Ministério Público, ainda que o amparo probatório não se mostre robusto ${ }^{13}$.

Apesar das críticas, respalda-se a prosecutorial discretion, pois, do contrário, a administração da justiça penal entraria em colapso. Diz a Suprema Corte que a atuação da promotoria seria estritamente técnica, gozando de presunção de correção. Noticia Rossana Gambini Musso que, nada obstante as denúncias levadas a cabo pela American Bar Association, segundo as quais a maioria das investigações instauradas para apurar casos de corrupção pública teve como suspeitos agentes políticos envolvidos em perseguições raciais contra afrodescendentes e hispânicos, entre os quais promotores, a Suprema Corte não reviu a sua posição.

Geraldo Prado destaca que a confiança quase absoluta no Estado e nas instituições repousa, em grande parte, nas concepções de contrato social desenvolvidas por Thomas Hobbes e John Locke, criando o caldo absolutamente propício ao desenvolvimento do plea bargaining. Na medida em que, para o primeiro, "o Estado é fruto do medo e constitui a ferramenta que permite às pessoas terem esperança de viver em paz e implementar todas as suas potencialidades”, enquanto, para o segundo, "o caráter protetivo do sistema legal, sua fundação nas raízes da própria sociedade, levam o sujeito individual e concreto...a ter em regra em relação de fidelidade com a lei”, não causa espécie que se veja como correto o atuar acusatório estatal, e normal o imputado abdicar de certas garantias em prol de um acordo com o mencionado Estado-acusação, presumindo-se justa a avença. ${ }^{14}$ Não por acaso as razões comumente evocadas a favor da Justiça Penal Negocial perpassam

12 VASCONCELLOS, Vinicius G. Barganha e Justiça Criminal Negocial. São Paulo: IBCCRIM, 2015, p. 185.

13 COUTINHO, Jacinto; CARVALHO, Edward Rocha de. Acordos de delação premiada e o conteúdo ético mínimo do Estado. Revista de Estudos Criminais, São Paulo, ano VI, n. 22, abr./jun. 2006, p.76.

14 PRADO, Geraldo. Elementos para uma Análise Crítica da Transação Penal, Rio de Janeiro, Lumen Juris, 2003, p. 78-83. 
pela constatação de a maioria dos réus ser, efetivamente, culpada, daí não contestar a acusação; pela economia representada pela barganha, reduzindo, significativamente, os custos de um processo criminal; e pela eficiência na elucidação de casos complexos, e, mesmo, na construção de novas demandas, notadamente relacionadas à corrupção e ao tráfico de entorpecentes ${ }^{15}$. John Kaplan chega a mencionar que, se por hipótese fosse banida a barganha no ordenamento estadunidense, os acordos continuariam a acontecer, diretamente com o juiz, potencializando o sigilo em detrimento da publicidade ${ }^{16}$.

Embora admita a possibilidade de haver discriminatory prosecution em virtude de acusações seletivas - selective prosecution -, a Corte exige a demonstração do "impacto discriminatório" - discriminatory effect -, citando casos nos quais idêntico fenômeno restou verificado, e do "escopo discriminatório" - discriminatory purpose -, isto é, o menosprezo por qualquer critério técnico, norteando-se por critérios de raça, religião ou particular animosidade - vindictive prosecution -, de maneira a gerar, ao menos, dúvida razoável quanto à correção da atividade persecutória. Trata-se de dificílimo ônus probatório, porquanto as promoções acusatórias, inclusive as de teor investigatório - discovery -, dispensam fundamentação. ${ }^{17}$

Ante o cenário, percebe-se o quão tímido é o controle jurisdicional, buscando verificar, fundamentalmente, se a manifestação de vontade do imputado foi voluntária e inteligente.

Voluntariedade, segundo a Regra Federal no 11, (b), (2), significa não ser a colaboração fruto de ameaça, violência física ou de promessas juridicamente inatendíveis, devendo o juiz indagá-lo a respeito, pessoalmente, em audiência - open court. A norma tem sido interpretada restritivamente pelos Tribunais, admitindo-se, a contrario sensu, coerções psicológicas, como a overcharging - acusações excessivamente graves ou abundantes, como estratégia à obtenção de acordo, em geral nos moldes do item (c) (1) (A) da Regra Federal no 11 (retirada de algumas

15 ALKON, Cynthia. Ob. cit., p. 391-393.

16 KAPLAN, John. American Merchandizing and the Guilty Plea: Replacing the Bazaar with the Department Store, Am. J. Crim. Law, vol. 5, 1977, p. 220 apud ALKON, Cynthia. Ob. cit., p. 392, nota 249.

17 MUSSO, Rosanna Gambini. Ob. cit., p. 39-41. 
das imputações) - ou o package deals- existindo muitos envolvidos, em vez de negociar individualmente, a promotoria oferece proposta única, global, cujo implemento depende da aquiescência geral.

Três precedentes bem ilustram o asseverado.

Brady v. U.S. (1970) ${ }^{18}$ versou sobre um rapaz, Brady, acusado de extorsão mediante sequestro. Se fosse levado ao Grand Jury, os jurados poderiam recomendar-lhe a pena de morte; se preferisse o julgamento por um Juízo monocrático - bench trial -, a resposta penal máxima seria a prisão perpétua. Embora, primeiro, Brady tenha escolhido o processo e julgamento pelo Júri, posteriormente recuou e optou por declararse culpado, recebendo do Juízo singular uma reprimenda de cinquenta anos de reclusão, depois reduzida para trinta. Após, recorreu à Suprema Corte, a fim de invalidar sua declaração de culpa, alegando que esta não havia sido livre, mas sim fruto da coerção representada pela previsão legal de lhe ser imposta a pena de morte, caso escolhesse o julgamento pelo Júri. A Corte, na esteira do voto condutor do Justice White, indeferiu o pleito, obtemperando que sua declaração de culpa não foi coagida - coerced -, e sim causada - caused - pela legislação ${ }^{19}$.

Em Bordenkircher v. Hayes $(1978)^{20}$, a acusação atrelou-se à falsificação de notas bancárias, no valor total de $\$ 88,30$ - oitenta e oito dólares e trinta centavos -, cuja reprimenda variava de dois a dez anos de reclusão. A promotoria afirmou que, caso não se declarasse culpado, qualificaria o imputado como delinquente habitual (reincidente), circunstância que, segundo a legislação local - Kentucky Habitual Criminal Act - tornava a reprimenda perpétua. Hayes optou pelo julgamento, foi qualificado pela promotoria da forma prometida e, ao final, condenado à prisão perpétua. Recorreu, então, à Suprema Corte, que, no entanto, não

18 Disponível em: <https://supreme.justia.com/cases/federal/us/397/742/ case.html . Acesso em: 6 fev. 2017. Sublinha-se que o inteiro teor do precedente se encontra disponível apenas na versão impressa, não se mostrando acessível por meio do sítio eletrônico oficial da Suprema Corte NorteAmericana.

19 Whitebread, Charles H.; SLOBOGIN, Christopher. Criminal Procedure, An Analysis of Cases and Concepts. $4^{\mathrm{a}}$ ed. Nova Iorque: University Textbook Series, Foundation Press, 2000. p. 671.

20 Disponível em: <https://supreme.justia.com/cases/federal/us/434/357/case. html>. Acesso em: 6 fev. 2017. Reportamo-nos à observação revelada na nota n ${ }^{\circ} 18$. 
viu nada de irregular na conduta do promotor, encarando-a como mera estratégia desenvolvida para alcançar o acordo ${ }^{21}$.

Em Pollard v. U.S. (1992) ${ }^{22}$, precedente da Corte do Circuito da Capital (D.C.Cir.), o réu foi acusado de conspiração internacional, porquanto teria passado informações confidenciais do Departamento de Defesa norte-americano ao governo de Israel. A fim de facilitar a obtenção do acordo, a promotoria estendeu a acusação à mulher de Pollard, seriamente doente à época, enquadrando-a como partícipe. Ambos pactuaram, mediante a promessa de tratamento penal mais benigno à esposa. Posteriormente, Pollard impugnou a declaração de culpa, obtemperando que teria sido fruto de uma coação mental e emocional levada a cabo pela promotoria. A Corte, entretanto, ao negar o pleito, alegou que a manifestação da vontade do réu foi perfeitamente livre, eis que não houve ameaças ilícitas ou abusivas, violência, nem tampouco promessas falsas ou impróprias (v.g., suborno). A Corte chegou a asseverar que Pollard ainda deveria agradecer o package deal, considerados os benefícios concedidos à consorte. ${ }^{23}$

Cumulativamente à voluntariedade exige-se a inteligência, isto é, o imputado há de ter consciência do conteúdo e das consequências do pacto avençado com a promotoria, devendo o juiz, pessoal e obrigatoriamente, adverti-lo, nos termos da Regra Federal no 11, (b), (1),

21 Saltzburg, Stephen A; Capra, Daniel. J. American Criminal Procedure, Cases and Commentary.5 ${ }^{a}$ ed. St. Paul, Minn.: American Casebook Series, West Publishing Co., 1996, p. 828-829 e MUSSO, Rosanna Gambini (ob. cit., p. 42-43) apontam que tal julgado não foi unânime na Suprema Corte, contando com a dissensão dos Justices Blackmun, Brennan, Marshall e Powell. O primeiro, Justice Blackmun, obtemperou que haveria fortes razões de equidade - fairness - a censurar a manipulação da acusação pela promotoria, que deve ser deduzida logo no início do procedimento negocial, servindo de referencial para eventual acordo, sob pena de chancelar, ao final, uma linha de atuação absolutamente deturpada, "invertida" (filliped thread attheend). O último, Justice Powell, foi incisivo ao declarar que a estratégia encetada pelo promotor não refletia o interesse público por uma sentença apropriada, mas o simples desejo de evitar a todo o custo o julgamento, ainda que isso representasse uma condenação absolutamente desarrazoada.

22 Disponível em: <https://supreme.justia.com/cases/federal/us/352/354/ case.html>. Acesso em: 6 fev. 2017. Reportamo-nos à observação revelada na nota $\mathrm{n}^{\circ} 18$.

23 SALTZBURG, Stephen A.; CAPRA, Daniel J. Ob. cit., pp. 832-834. 
da natureza da imputação criminosa veiculada na declaração de culpa firmada, incluindo a escala penal correspondente, bem como as particularidades da execução da pena e os requisitos necessários à conquista do livramento condicional. Igualmente deve ser alertado da possibilidade de o Juízo divergir da proposta de condenação e/ou de sanção apresentada e do dever de indenizar a vítima, se existir previsão legal nesse sentido, incluindo confisco de bens - Rule 11 (b) (1) (G, H, I). Ainda será informado do direito a um advogado, para representá-lo ao longo de todo o processo, providenciado o Estado um profissional, caso não tenha - Rule 11 (b) (1) (D); do direito de declarar-se inocente, de ser julgado por um júri (tried by jury), bem como das garantias à não autoincriminação e ao contraditório em juízo (the right to confront and cross-examine adverse witness) - Rule 11 (b) (1) (B, C, D, E), da renúncia ao julgamento, na medida em que se declara culpado ou não contesta a imputação - Rule 11 (B) (1) (F); do dever de dizer a verdade ao Juízo, caso decida inquiri-lo, sob juramento oficial, na presença de seu defensor, acerca dos crimes em relação aos quais se declarou culpado, sob pena de as respostas serem usadas em seu desfavor, em futuro processo de perjúrio ou de falso testemunho - Rule 11 (b) (1) (A); de renúncia ao direito de apelo ou de ataque colateral à sentença - Rule 11 (b) (1) (N).

Ínsita ao requisito da inteligência - knowing and intelligent factor - é a higidez mental do acusado, de modo que possa, racionalmente, compreender o significado e os desdobramentos da declaração de culpa. Trata-se do que a doutrina e a jurisprudência norte-americanas chamam de competency to plead guilty. A Suprema Corte norte-americana, em Godinez v. Moran (1993) ${ }^{24}$, entendeu, por maioria, que o grau de discernimento exigível para validar uma declaração de culpa é o mesmo necessário para que o réu seja submetido a julgamento, nunca menor, pois o plea of guilty deságua em uma sentença penal condenatória. ${ }^{25}$

A inteligência pressupõe, ainda, o acesso, pela defesa técnica, às provas existentes contra o imputado. Tal direito, todavia, restringe-se às

24 Disponível em: <https://supreme.justia.com/cases/federal/us/509/389/ case.html>. Acesso em: 6 fev. 2017. Reportamo-nos à observação revelada na nota $\mathrm{n}^{\circ} 18$.

25 SALTZBURG, Stephen A.; CAPRA, Daniel J. Ob. cit., p. 836-837. 
provas exculpantes - exculpatory evidence -, ou seja, às peças de informação efetivamente favoráveis ao réu. A promotoria não está obrigada a revelar as evidências restantes, nem tampouco esclarecer se existiriam outras. Como qualquer negócio, não estariam as partes compelidas a exibir as vulnerabilidades. Se a tese acusatória é frágil, que tal debilidade apareça somente no julgamento, conforme decidiu a Corte de Nova Iorque em People v. Jones (1978) ${ }^{26}$. E a Suprema Corte, em U.S. v. Bagley $(1985)^{27}$, foi além, ao declarar que o não acesso da defesa ao acervo probatório da acusação, mesmo às exculpantes, apenas vicia o negócio jurídico se o acusado provar (ônus seu) que, caso tivesse tomado ciência deste, não teria pactuado, preferindo o julgamento convencional, com todos os riscos a ele inerentes. ${ }^{28}$

Diante do quadro, embora o juiz deva, antes de homologar o acordo, verificar a existência de suporte probatório mínimo, na linha preconizada na Regra Federal no 11 (b) (3), a rejeição é excepcional, porquanto as negociações entre promotoria e defesa gravitam em torno da acusação que será deduzida em juízo - charge bargain. Em virtude do adversary system, o juiz não possui o menor controle sobre a atividade acusatória desempenhada pela promotoria, orientada pela mais absoluta discricionariedade (prosecutorial discretion). Os tribunais prendem-se muito à acusação deduzida em juízo, nelas interferindo apenas se manifestamente abusivas. Dessa forma, desde que o negócio tenha como objeto a imputação que será deduzida em juízo, se estiver aparentemente regular, inexistirá controle jurisdicional. ${ }^{29}$

O inverso, ou seja, o Judiciário deferir o prêmio, independentemente de acordo prévio com a acusação, soa impensável, em um modelo como o adversary system adotado no processo penal estadunidense.

26 Disponível em: <http://www.leagle.com/decision/197812044NY2d76_1112/ PEOPLE\%20v.\%20JONES> Acesso em: 6 fev. 2017. O precedente tampouco está disponível no sítio eletrônico da Corte de Apelação do Estado de Nova Iorque.

27 Disponível em: <https://supreme.justia.com/cases/federal/us/473/667/ case.html>. Acesso em: 6 fev. 2017. Reportamo-nos à observação revelada na nota $\mathrm{n}^{\mathrm{o}} 18$.

28 WHITEBREAD, Charles H.; SLOBOGIN, Christopher. Ob. cit., p. 670, notas 23 e 24.

29 WHITEBREAD, Charles H.; SLOBOGIN, Christopher. Ob. cit., p. 677. 
Mesmo quando já homologada judicialmente a avença, o descumprimento desta pela promotoria enseja, quando muito, a anulação do pacto, e não a execução específica. Em Santobello v. New York $(1971)^{30}$, no qual o promotor que sucedeu o anterior voltou atrás, após a chancela judicial, propondo a pena máxima de um ano contra o réu, em desrespeito ao pacto, que não autorizava qualquer recomendação expressa de sanção pela promotoria, a Suprema Corte limitou-se a invalidar a declaração de culpa, por ofensa ao devido processo legal, ante o descumprimento do acordado. ${ }^{31}$ Anulado o pacto, restam ao imputado duas opções: ou aceitar a nova proposta formulada pela promotoria, ou submeter-se ao julgamento, conforme entendeu, v.g., o Tribunal do $3^{\circ}$ Circuito Federal em United States $v$. Moscahlaidis (1989) ${ }^{32}$. Poucas são as vozes favoráveis ao direito do acusado à execução do acordo antes acertado, conforme defendem Charles H. Whitebread e Christopher Slobogin. ${ }^{33}$

\section{Colaboração premiada na Itália}

$\mathrm{Na}$ Itália, o exercício da ação penal pública é munus privativo do Ministério Público, orientado pelo princípio da obrigatoriedade, que possui previsão constitucional, ex vi do artigo 112 da Constituição da República Italiana, in litteris: "O Ministério Público possui a obrigação de exercer a ação penal”. O artigo 50, comma 1, do Código de Processo Penal (CPP) italiano reitera o princípio ao prescrever que, in textus, "o Ministério Público exerce a ação penal quando não subsistem os pressupostos para o pedido de arquivamento".

Isso significa que o Ministério Público não é um órgão acusatório contumaz. Evidentemente que não. Tal qual no Brasil, o Parquet somente deflagra a ação penal quando estiverem presentes as condições

30 Disponível em: <https://supreme.justia.com/cases/federal/us/404/257/ case.html>. Acesso em: 6 fev. 2017. Reportamo-nos à observação revelada na nota $\mathrm{n}^{\mathrm{o}} 18$.

WHITEBREAD, Charles H.; SLOBOGIN, Christopher. Ob. cit., p. 678.

32 Disponível em: <https://casetext.com/case/us-v-moscahlaidis >. Acesso em: 6 fev. 2017. O precedente não está disponível no sítio eletrônico oficial da Corte de Apelação do Terceiro Circuito Federal.

33 WHITEBREAD, Charles H.; SLOBOGIN, Christopher. Ob. cit., p. 680. 
para tanto, incluindo a existência de lastro probatório mínimo necessário ao ajuizamento da denúncia. ${ }^{34}$

Diferentemente dos EUA, na Itália transaciona-se o procedimento, com reflexos na sentença penal condenatória, atenuando-se a pena e/ou os seus efeitos, ou diretamente a reprimenda. O primeiro é negociado em sede de juízo abreviado ou monitório.

O juízo abreviado tem lugar ainda na fase da audiência preliminar, quando o acusado - a iniciativa é dele - pede o imediato julgamento da pretensão acusatória, com a anuência do Ministério Público, conforme assinala a Françoise Tulkens ${ }^{35}$. O imputado abdica das garantias processuais - contraditório e ampla defesa, principalmente -, aquiescendo que o Judiciário decida a demanda com lastro exclusivo nas peças de informação colhidas na fase investigatória - art. 438, comma 1, do Código de Processo Penal. O imputado pode, ainda, propor o julgamento abreviado condicionado à produção probatória, se necessária ao exame do mérito e desde que compatível com a almejada economia processual. Se acolhido o pedido, o Ministério Público pode apresentar provas em sentido contrário - art. 438, comma 5. A Corte Constitucional Italiana, em 27 de julho de 2001, declarou a constitucionalidade desse procedimento. ${ }^{36}$

Nada impede que o réu venha a ser absolvido, mas, se condenado, receberá, em contrapartida à escolha do mencionado rito, a redução de um terço da reprimenda e, se cominada para o delito a pena de prisão perpétua, a sua substituição pela sanção privativa de liberdade por 30 anos, dada ao acusado, nos termos do artigo 442, comma 2, do Código de Processo Penal. Questionou-se a constitucionalidade do dispositivo, por fixar causa de diminuição da pena desconexa da imputação, desprezando a reprovabilidade em concreto do injusto e as circunstâncias

${ }^{34}$ MORELLO, Michele. Il Nuovo Processo Penale, parte generale. Padova: CEDAM, 2000, p. 82.

35 TULKENS, Françoise. Una Giustizia Negoziata?, Il processo penale in Itália. In: DELMAS-MARTY, Mireille; CHIAVARIO, Mario (Org.). Procedure Penale D'Europa. $2^{\text {a }}$ ed., Padova: CEDAM, 2001. p. 649.

36 CONSO, Giovanni; GREVI, Vittorio. Codice di Procedura Penale e Norme Complementari. Nova Edição. Milão: Giuffrè, 2001, p. 411, nota 3 ao art. 438 do CPP. Disponível em: <http://www.cortecostituzionale.it/actionRicercaMassima.do>. Acesso em: 6 fev. 2017. 
pessoais do infrator. Contudo, a Corte Constitucional italiana, em 14 de junho de 1990, declarou-o constitucional. ${ }^{37}$ Sobrevindo a condenação, o réu pode apelar, mas o Ministério Público apenas interporá apelação se o juiz implementar emendatio libelli, alterando a capitulação delituosa (artigo 443, comma 3, do Código de Processo Penal).

O procedimento por decreto penal, a seu turno, depende da iniciativa do Ministério Público. Findas as investigações, ainda na fase preliminar, o Parquet oferece ao Juízo um decreto penal condenatório, consistente na imediata aplicação somente de uma pena pecuniária (artigo 459, comma 1, do Código de Processo Penal) ou no mínimo legal, reduzido de até a metade (artigo 459, comma 2). O decreto igualmente aponta, se for o caso, o civilmente responsável pela reparação do dano à vítima (artigo 460, comma 2).

Aprovado pelo Juízo o decreto penal formalizado pelo Ministério Público, o acusado e o responsável civil indicado na proposta são notificados para manifestar-se. A notificação há de ser pessoal, sob pena de caducidade do decreto, restituindo ao Parquet o direito de deflagrar a ação penal.Regularmente notificado, o réu pode impugnar o decreto penal e indicar a observância de outro rito - pattegiamento ou abreviado, caso contrario se procederá com o rito imediato (artigo 461, comma 3, do CPP). Caso não deduza qualquer oposição, quedando-se inerte, o decreto penal proposto pelo Ministério Público é homologado pelo Juízo. O acusado, em contrapartida, fica liberado do pagamento das custas processuais, das penas acessórias e do dever de indenizar, por inexistir confissão expressa de culpa. O título condenatório tampouco impede futura suspensão condicional da pena em caso de posterior condenação criminal. E, ao cabo de cinco anos, se a condenação tinha como objeto um crime, ou dois, ou se versava sobre contravenção, apagamse todos os efeitos penais da sentença, exceto se o condenado cometer novo injusto da mesma natureza - artigo 460, comma 5, do CPP.

O patteggiamento, previsto nos artigos 444 a 448 do Código de Processo Penal, importa, por outro lado, negociação direta da pena, em

37 CONSO, Giovanni; GREVI, Vittorio. Ob. cit., p. 414, nota 3 ao art. 442. Disponível em: <http://www.cortecostituzionale.it/actionRicercaMassima. do>. Acesso em: 6 fev. 2017. 
vez do rito. O recebimento de reprimenda mais branda não é efeito do procedimento pactuado, mas o objeto do acordo ${ }^{38}$.

Consubstancia, em regra, um acordo conjunto do Ministério Público com o acusado - artigo 444, comma 1. O consentimento do Parquet acarreta a renúncia ao direito de apelar - artigo 448, comma 2. Nada impede, entretanto, que o réu proponha, diretamente, a pena a ser aplicada, vindo o juiz a homologá-la, independentemente da aquiescência do Ministério Público - artigo 446, comma 6 -, hipótese na qual o Parquet poderá apelar da sentença - artigo 448, comma 8. A eventual oposição da vítima é irrelevante à chancela judicial do pacto - artigo 444 , comma 2, do CPP. Por resultar na prolação de sentença penal condenatória, é imprescindível a existência de elementos idôneos que sustentem a acusação,, sob pena de rejeição pelo juiz - artigo 444, comma 2. Não alcança toda e qualquer infração penal, nem tampouco acusado, mostrando-se vedado, por exemplo, ao delinquente profissional, habitual e por tendência, na linha do preceituado no artigo 444, comma 1bis. Condiciona-se, por vezes, à restituição integral do objeto ou do proveito da infração penal, segundo dispõe o próprio artigo 444, comma 1ter.

O imputado autoriza lhe seja aplicada uma pena restritiva de direitos ou pecuniária, reduzida de até um terço, ou mesmo uma reprimenda privativa de liberdade, desde que, minorada também de até um terço, não ultrapasse cinco anos de detenção, cumulativamente ou não com sanção pecuniária - artigo 444, comma 1 . O sentenciado aufere, basicamente, as mesmas benesses previstas no procedimento monitório, conforme artigo 445.

O juiz exerce sobre o patteggiamento um controle de legalidade, chancelando-o se existir lastro probatório razoável relativo à existência e à autoria do crime, à tipicidade, sem excludentes da ilicitude e da culpabilidade, nem tampouco causas extintivas da punibilidade. Incumbe-lhe apreciar, ainda, a congruência (proporcionalidade) entre a reprimenda proposta e a imputação dirigida ao acusado - art. 444, comma 2, do CPP.

38 PERRODET, Antoinette. Il processo penale in Itália. In: DELMAS-MARTY, Mireille; CHIAVARIO, Mario (Org.). Procedure Penali D'Europa. $2^{\mathrm{a}}$ ed. Padova: CEDAM, 2001. p. 314-315. 
À semelhança da experiência norte-americana, em que o estudo da plea bargaining já compreende a delação premiada, uma vez que muitos acordos em torno da capitulação delitiva e/ou da reprimenda aplicável ao réu condiciona-se à potencial colaboração com a persecução, na Itália a negociação, quer em torno do procedimento a ser adotado, quer acerca da reprimenda, não raro se atrela, veladamente, à disposição do acusado para auxiliar o Estado na apuração e repressão da atividade delituosa.

Embora a colaboração, incluindo a confissão simples, não integre o rol de atenuantes do art. 62 do Código Penal italiano, o art. 62-bis explicita o caráter meramente exemplificativo desse elenco, ao anunciar que o juiz pode levar em consideração circunstâncias diversas que também justificariam a minoração da reprimenda. Tal arcabouço normativo constituiu terreno fértil à propagação da colaboração premiada. Na ausência de dispositivo próprio, especificando o benefício correspondente à determinada atenuante, vale a regra geral do art. 65: a prisão perpétua é substituída pela pena de reclusão, de vinte a vinte e quatro anos, ao passo que as demais comportam redução de até um terço.

Luigi Ferrajoli, debruçando-se sobre o processo penal italiano, observa que “(...) por meio destes procedimentos é de fato introduzido no nosso ordenamento o discutido instituto da colaboração premiada com a acusação. Com o agravante de que ela não foi codificada abertamente, mediante a previsão de uma circunstância atenuante, mas de forma sub-reptícia, por meio de um mecanismo idôneo a incentivar os procedimentos acordados e desencorajar o juízo ordinário, com todo o seu sistema de garantias; que ela não é mais uma medida excepcional, conjuntural e limitada a determinados tipos de procedimentos, mas sim um novo método processual codificado para todos os processos; que, enfim, o benefício da pena não será concedido por um juiz no curso de um juízo público, mas pela própria acusação no curso de uma transação destinada a desenvolver-se em segredo". ${ }^{39}$

A crítica de Ferrajoli não passou despercebida, haja vista a edição do Decreto-Lei no 8, de 15 de janeiro de 1991, convertido, em 15 de março seguinte, na Lei $\mathrm{n}^{\circ} 82$, posteriormente modificada, em 13 de

39 FERRAJOLI, Luigi. Direito e Razão, Teoria do Garantismo Penal. São Paulo: RT, 2002. p. 601. 
fevereiro de 2001, pela Lei $n^{\circ} 45$, com o escopo de disciplinar a proteção às testemunhas, incluindo o réu colaborador. Curiosamente, esse diploma legal não se ocupou apenas desse assunto, ao contrário, o Capítulo I dedica-se à repressão da extorsão mediante sequestro. $\mathrm{O}$ artigo $6^{\circ}$, no entanto, prevê a delação como atenuante especial, anunciando que, se for de "excepcional relevância", encurtando o tempo de duração do cárcere da vítima, resgatando-a com a incolumidade preservada, a reprimenda pode ser diminuída de até um terço.

O Capítulo II versa sobre a proteção às testemunhas, bem como aos acusados colaboradores. Não chega a disciplinar o tema de maneira geral, porquanto o artigo $9^{\circ}$, comma 2 , restringe o alcance da lei aos delitos de terrorismo, aos subversivos à ordem constitucional - v.g., crime organizado, com menção expressa à máfia, haja vista, para ilustrar, o art. 11 -, aos listados no artigo 51, comma 3-bis, do Código de Processo Penal, bem como à prostituição infantil e à exploração de material pornográfico, inclusive virtualmente (artigos. 600-bis, 600-ter, 600-quater e 600-quater.1, todos do Código Penal). A objeção de Ferrajoli à ausência de um regramento voltado, especificamente, à disciplina da delação premiada foi, portanto, parcialmente satisfeita, permanecendo a lacuna quando implementada para delitos não abarcados pelo mencionado Decreto-Lei $n^{\circ} 8$, convertido na Lei $n^{0} 82$, alterada pela de $n^{0} 45$.

A colaboração, para ser premiada, deve reunir notícias e provas que permitam não apenas a reconstrução do fato criminoso em julgamento, mas a revelação de outros injustos de maior gravidade e de grupos criminosos, a captura dos delinquentes, a apreensão de bens que sejam objeto, proveito ou instrumento das infrações penais, conforme o art. 16-quater, comma 1, c/c art. 16-quinquies, comma 1. A delação premiada pode ser implementada também em prol do condenado, que decida auxiliar a Justiça, fornecendo-lhe informações nos moldes acima, em troca de benefícios como livramento condicional e colocação em prisão domiciliar, ex vi do art. 16-nonies, comma 1.

\section{Colaboração premiada no Brasil}

Embora a Lei $n^{0}$ 9807/99 discipline, em geral, a delação premiada no ordenamento pátrio, não estabeleceu o procedimento próprio 
ao seu implemento, limitando-se a listar os requisitos necessários à concessão da benesse, conforme revelam os artigos 13 e 14. Tal lacuna foi reiterada nas demais hipóteses de colaboração, restringindo-se o legislador a fixar as premiações e os pressupostos imprescindíveis à obtenção. Caso a cooperação alcance os resultados previstos em lei, o juiz premia o imputado, independentemente da anuência do Ministério Público.

A Lei $n^{\circ} 12.850 / 13$ foi a única a regular o procedimento atinente à colaboração, nos artigos $4^{\circ}$ a $7^{\circ}$. A par dos benefícios enumerados no caput do artigo $4^{\circ}$, e dos resultados a serem alcançados para o deferimento, as disposições procedimentais aplicam-se, analogicamente, às demais hipóteses de delação, nada obstante a especialidade, afinal, nos moldes do artigo $3^{\circ}$ do Código de Processo Penal, “a lei processual penal admitirá interpretação extensiva e aplicação analógica, bem como o suplemento dos princípios gerais de direito". ${ }^{40}$

A partir de uma interpretação textual dos $\S \S 2^{\circ}, 6^{\circ}$ a $9^{\circ}$ e 11 do artigo $4^{\circ}$ da Lei $n^{\circ} 12.850 / 13$, parte substancial da doutrina tem condicionado a premiação da colaboração ao pacto previamente celebrado entre o Ministério Público e o imputado, homologado judicialmente ${ }^{41}$. Por conseguinte, autores como Cleber Masson e Vinícius Marçal ${ }^{42}$, bem como Andrey Borges de Mendonça ${ }^{43}$, debruçando-se sobre o requerimento de perdão judicial pelo Ministério Público, previsto no $\$ 2^{\circ}$ do artigo $4^{\circ}$ da Lei $n^{\circ} 12.850 / 13$, e o não oferecimento da denúncia, nos moldes do $\S 4^{\circ}$ do citado artigo $4^{\circ}$, lecionam ser caso de arquivamento, mas pautado em um acordo de não denunciar ou de imunidade, que seria uma "causa extintiva da punibilidade sui generis", fazendo coisa julgada material, após a homologação judicial, sem possibilidade de retomar a ação penal em face do colaborador.

40 SANTOS, Marcos Paulo Dutra. Ob. cit., p. 123-124.

41 SENNA, Gustavo, BEDÊ JUNIOR, Américo, A Colaboração Premiada no Brasil. In: ZANOTTI, Bruno Taufner, SANTOS, Cleopas Isaías (org.) Temas Atuais de Polícia Judiciária, $2^{a}$ edição, Salvador, Jus Podivm, 2016. p. 376-379; DIPP, Gilson. A “delação” ou colaboração premiada. Brasília: IDP, 2015, p. 43.

42 MASSON, Cleber e MARÇAL, Vinícius. Crime Organizado. São Paulo: Método, 2015, p. 119-120.

43 MENDONÇA, Andrey Borges de. A colaboração premiada e a nova Lei do Crime Organizado (Lei 12.850/2013). Custos legis - Revista Eletrônica do Ministério Público Federal. vol. 4, 2013, p. 20-22. 
Outros, como Eugênio Pacelli de Oliveira ${ }^{44}$, Eduardo Araújo da $S_{\text {Silva }}{ }^{45}$, Rogério Filippetto e Luísa Carolina Vasconcellos Chagas Rocha ${ }^{46}$, por sua vez, reputam inconstitucional a intervenção da autoridade policial nas tratativas objetivando a colaboração, conforme previsto nos $\S \S 2^{\circ}$ e $6^{\circ}$ do artigo $4^{\circ}$ da Lei $n^{\circ} 12.850 / 13$, por lhe faltar legitimidade ad causam, considerada a titularidade privativa da ação penal pelo Ministério Público, segundo preceituado no artigo 129, I, da Constituição ${ }^{47}$. Encarase a delação premiada como de iniciativa privativa do Ministério Público, à semelhança do verificado na transação penal e na suspensão condicional do processo. A Procuradoria-Geral da República, aliás, formalizou a Ação Direta de Inconstitucionalidade $\mathrm{n}^{0}$ 5.508/DF em face dos mencionados dispositivos, postulando a declaração de inconstitucionalidade da legitimidade dos delegados para pactuar acordos de colaboração, ou, subsidiariamente, dar interpretação conforme a Constituição para assentar a indispensabilidade da participação do Ministério Público em todas as fases de elaboração do acordo, desconsiderando-o caso não o avalize. A ação foi distribuída ao Ministro Marco Aurélio, que acionou o artigo 12 da Lei $n^{\circ}$ 9.868/1999, indeferindo o pedido liminar de suspensão da legitimidade da autoridade policial, por se tratar de preceitos em vigor desde 2013, a recomendar o julgamento definitivo pelo Colegiado Maior.

O Pleno do Supremo, aliás, ao assentar a natureza da colaboração premiada como negócio jurídico processual, preconizou que “(...) os princípios da segurança jurídica e da proteção da confiança tornam indeclinável o dever estatal de honrar o compromisso assumido no acordo de colaboração, concedendo a sanção premial estipulada, legítima contraprestação ao adimplemento da obrigação por parte do colaborador (...)”48.

44 OLIVEIRA, Eugênio Pacelli de. Curso de Processo Penal. 19ª ed. São Paulo: Atlas, 2015, p. 853-854.

45 SILVA, Eduardo Araújo da. Organizações Criminosas. $2^{\mathrm{a}}$ ed. São Paulo: Atlas, 2015, p. 60-61.

46 FILIPPETTO, Rogério; ROCHA, Luísa C. V. C. Colaboração Premiada. Belo Horizonte: D’Plácido, 2017. p. 146-154.

47 Em idêntico diapasão: SENNA, Gustavo; BEDÊ JÚNIOR, Américo, A Colaboração Premiada no Brasil, ob. cit., p. 376-378; PEREIRA, Frederico Valdez, O Procedimento da Colaboração Premiada e as Inovações da Lei $\mathrm{n}^{\circ}$ 12.850/13, p. 336-337;

48 HC 127.483/PR, Rel. Min. Dias Toffoli, j. em 27/8/2015, DJe de 4/2/2016. 


\section{Cooperação Unilateral Premiada}

A visão segundo a qual a colaboração premiada seria um negócio jurídico processual não pode ser aceita integralmente, porquanto, além de não contemplar o instituto em toda a sua abrangência, mostrase contra legem.

Premiar a delação pode, indiscutivelmente, passar pela celebração de um negócio jurídico processual entre o imputado e o Ministério Público, encaminhado à homologação judicial. Mas não é esta a única forma de premiá-la, inclusive na Lei $\mathrm{n}^{\circ} 12.850 / 13$, porquanto a cabeça do artigo $4^{\circ}$ refere-se a "requerimento das partes", listando os resultados a serem alcançados para a concessão do benefício. A menção, sem ressalvas, às "partes" revela a legitimidade do acusado para cooperar e ser premiado, em razão dos frutos obtidos a partir desta, independentemente de qualquer aval do Parquet. Sustentar posição diversa ofenderia o devido processo legal, encartado no artigo $5^{\circ}$, LIV, da Constituição, criando-se óbices à aquisição de benesses libertárias não previstos em lei. A violação à aludida garantia fundamental potencializa-se caso se almeje projetar o referido modelo, próprio à repressão às organizações criminosas, às demais hipóteses de colaboração, nas quais a premiação vincula-se apenas à concretização dos fins previstos em lei. Haveria acintosa analogia in malam partem.

Descabe, igualmente, aproximar a colaboração à transação penal e à suspensão condicional do processo. As duas últimas incidem no exercício da ação penal, que tem no Ministério Público o seu titular (artigo 129, I, da Constituição), logo é aceitável que a iniciativa da proposta seja sua. Analogamente à ação penal pública, representam um dever-poder ${ }^{49}$, cujo não exercício injustificado dá ao juiz a possibilidade de acionar o artigo 28 do Código de Processo Penal, deixando, de todo modo, com o Parquet a palavra final acerca do seu implemento ou não.

49 Embora seja mais comum o emprego da expressão "poder-dever", "dever -poder" soa mais adequado, pois o conjunto de prerrogativas (poder) conferido a um agente público decorre do munus (dever) que lhe foi confiado pela lei. O dever é pressuposto do poder. Nesse sentido: BANDEIRA DE MELLO, Celso Antônio. Curso de Direito Administrativo, 16a edição, São Paulo: Malheiros, 2003. p. 62-63. 
Nessa linha, destaca-se o Enunciado n ${ }^{0} 696$ de Súmula do STF ${ }^{50}$, referente à suspensão, mas extensível à transação, porquanto idêntica a ratio. E, mesmo assim, tal orientação conhece oposição de parte substancial da doutrina, que enxerga na transação e na suspensão direitos públicos subjetivos do imputado, bastando que estejam preenchidos os requisitos legais. Se presentes, seriam passíveis de deferimento pelo juiz, em havendo pedido da defesa, independentemente da oposição do Ministério Público, conforme articulam Weber Martins Batista ${ }^{51}$, Damásio Evangelista de Jesus ${ }^{52}$ e Fernando da Costa Tourinho Filho ${ }^{53}$.

Outro segmento doutrinário, em contrapartida, advoga, em relação à transação penal, que a outorga pelo juiz, em desconformidade com o desiderato do Ministério Público, de fato seria uma interferência indevida no exercício da ação penal, em detrimento do sistema acusatório. Sem embargo, repercutindo a transação na preservação do estado de inocência e da liberdade do imputado, não há como ser do Ministério Público, titular da pretensão acusatória, e, portanto, parte, a deliberação final em relação à admissibilidade e à pertinência do benefício, considerados o devido processo legal e a inafastabilidade da jurisdição, esta última versada no artigo $5^{\circ}, \mathrm{XXXV}$, da Constituição. Por conseguinte, caso entenda devida a transação, a não formulação da proposta, em prol da denúncia, permitiria ao juiz rejeitar a última, por falecer condição para o seu regular exercício - a viabilidade da transação obstaculizaria a formalização da ação penal condenatória, atuando como verdadeira condição negativa de procedibilidade ${ }^{54}$. A admissibilidade da suspen-

50 "Reunidos os pressupostos legais permissivos da suspensão condicional do processo, mas se recusando o promotor de justiça a propô-la, o juiz, dissentindo, remeterá a questão ao Procurador-Geral, aplicando-se por analogia o art. 28 do Código de Processo Penal".

51 BATISTA, Weber Martins; FUX, Luiz. Juizados Especiais Cíveis e Criminais e Suspensão Condicional do Processo Penal. Rio de Janeiro: Forense, 1998, p. 321-322.

52 JESUS, Damásio Evangelista de. Ob. cit., p. 76-77.

53 TOURINHO FILHO, Fernando da Costa. Comentários à Lei dos Juizados Especiais Criminais. São Paulo: Saraiva, 2000, p. 96-99.

54 SANTOS, Marcos Paulo Dutra. Transação Penal. Rio de Janeiro: Lumen Juris, 2006, p.113. Soluções parecidas foram propostas por CARVALHO, Luis G. G. C.; PRADO, Geraldo L. M. Ob. cit., p. 112-114 e 119, atrelando a viabilidade da transação penal à ausência de justa causa, e NICOLITT, André, Juizados 
são condicional do processo, mutatis mutandis, surgiria como condição negativa de prosseguibilidade, devendo ser implementada pelo juiz, a pedido do réu, como consectário lógico do devido processo legal, cujo condutor e presidente é o magistrado, e não o Parquet ${ }^{55}$.

A delação premiada, por outro lado, consubstancia, a depender da hipótese, perdão judicial, sujeito, conforme indica o próprio adjetivo, à reserva de jurisdição. A quadra não muda quando resvala na aplicação da pena, outro munus jurisdicional. Atrelar a premiação, mesmo quando presentes os requisitos legais, a acordo previamente ajustado com o Ministério Público, daria ao último inaceitável ingerência em matérias exclusivamente jurisdicionais, em descompasso com o artigo $2^{\circ} \mathrm{da}$ Constituição, comprometendo a independência, a separação e a harmonia entres os Poderes da República.

Na medida em que o juiz, ao homologar o pacto, restringe-se a "verificar sua regularidade, legalidade e voluntariedade" (art. $4^{\circ}, \S 7^{\circ}$, da Lei ${ }^{\circ} 12.850 / 13$ ), deixando, para a sentença, a apreciação dos seus termos e da eficácia (art. $4^{\circ}, \S 11$ ), mostra-se claro que, alcançados os resultados previstos em lei, o colaborador terá direito público subjetivo à premiação, mas a benesse é de escolha privativa do Juízo ${ }^{56}$, afinal as partes não podem negociar o que não dispõem - pena e perdão judicial submetem-se à reserva de jurisdição. Atentos ao fenômeno, Humberto Dalla Bernardina de Pinho e José Roberto Sotero de Mello Porto classificam tais acordos como ultra partes, não consubstanciando negócio jurídico processual propriamente, afinal os pactuantes não definem inteiramente os seus efeitos, considerada a desvinculação do juiz aos prêmios listados. A única hipótese genuína de negócio jurídico processual corresponde ao $\S 4^{\circ}$ do art. $4^{\circ}$, consistente no não oferecimento da denúncia como contrapartida à cooperação, hipótese na qual

Especiais Criminais, Temas Controvertidos. Rio de Janeiro: Lumen Juris, 2002. p. 20-21, vinculando-a à falta de interesse de agir. Saliente-se que a orientação de Grandinetti não se estende à de Geraldo Prado.

NICOLITT, André. Ob. cit., p. 33.

56 TOURINHO NETO, Fernando da Costa, Delação Premiada, Colaboração Premiada, Traição Premiada Endurecimento das Decisões Judiciais. Afronta à Constituição Federal. Juiz Justiceiro. In: ESPIÑEIRA, Bruno, CALDEIRA, Felipe (orgs.), Delação Premiada, ob. cit., p. 504. 
o deslinde e as consequências da avença decorrem, exclusivamente, da autonomia da vontade das partes ${ }^{57}$.

Não por acaso na Itália, país de origem romana-continental como o Brasil, no qual os Direitos Penal e Processual Penal submetemse a balizas constitucionais infinitamente mais rígidas do que as encontradas nos Estados Unidos da América, o atuar ministerial, na justiça penal negociada, não ostenta discricionariedade sequer próxima à norte-americana. Como o procedimento abreviado e o patteggiamento, à semelhança da colaboração premiada, repercutem no teor da prestação jurisdicional a ser entregue, a concretização compete ao juiz, acolhendo pedido do imputado, apesar de eventual oposição do Ministério Público. Em suma: admite-se a cooperação unilateral.

Vinicius Vasconcellos e Bruna Capparelli observam, a propósito, que "(...) ponto fulcral do exemplo italiano é a necessidade de motivação da decisão do Ministério Público acerca do cabimento do patteggiamento e as consequências da recusa ilegítima. Em contraste com o modelo estadunidense, cuja ampla discricionariedade do promotor impede amplo controle acerca da barganha, na Itália os motivos da recusa são verificados pelo juiz, que, se entendê-la injustificada, assegurará a redução solicitada pelo acusado, mesmo após o transcorrer de todo o procedimento ordinário, consagrando assim o acordo como direito subjetivo do réu" 58 .

Não se olvide, ademais, que a colaboração premiada, por si só, encerra confissão complexa, pois, além de reconhecer a responsabilidade penal, o imputado vai além, disponibilizando informações que permitem, v.g. a identificação dos demais autores ou partícipes, a arrecadação total ou parcial do produto do crime, a prevenção de infrações penais correlatas, etc. Trata-se de valiosa ferramenta defensiva, manifestação de autodefesa e, por conseguinte, da ampla defesa. Condicionar

57 PINHO, Humberto; PORTO, José. Colaboração Premiada: Um Negócio Jurídico Processual? In: ESPIÑEIRA, Bruno, CALDEIRA, Felipe (orgs.), Delação Premiada, ob. cit., 127-138.

58 VASCONCELLOS, Vinicius G.; CAPPARELLI, Bruna. Barganha no Processo Penal Italiano: Análise Crítica do Patteggiamento e das Alternativas Procedimentais na Justiça Criminal. Revista Eletrônica de Direito Processual REDP, vol. 15, jan./jun. 2015. p. 446. 
eventual premiação ao aval do Ministério Público simplesmente a cercearia, em descompasso com o artigo $5^{\circ}$, LV, da Constituição.

Finalmente, há de se atentar à razoabilidade, sob o prisma da proporcionalidade, vetor que tem se mostrado bastante presente no âmbito processual penal, norteando, por exemplo, as tutelas cautelares constritivas da liberdade, ex vi do artigo 282, I e II, do Código de Processo Penal, com a redação dada pela Lei $\mathrm{n}^{0} 12.403$, de 4 de maio de 2011, e a produção antecipada de provas, ex vi do artigo 156, I, do Código de Processo Penal, com a redação dada pela Lei $\mathrm{n}^{0} 11.690$, de 9 de junho de 2008. Se o negócio jurídico processual é premiado, fruto de um acordo bilateral, quanto mais se unilateral, ou seja, quando o imputado decide cooperar com os órgãos de repressão estatal independentemente de qualquer pacto previamente ajustado. Se o prêmio à colaboração é um incentivo ao arrependimento sincero, tendente à regeneração, que vem a ser o fim último da pena, conforme aponta parte da doutrina $^{59}$, com maior razão ainda há de ser reconhecido, e retribuído, quando prestada unilateralmente.

Embora Afrânio Silva Jardim também vislumbre na colaboração um negócio jurídico processual, adverte, com precisão, que “(...) não se pode impedir que o indiciado ou réu confesse um crime e forneça elementos de prova da participação de seus partícipes. Neste caso, sem o acordo de cooperação, caberia ou não ao juiz reduzir a pena privativa de liberdade, na proporção permitida expressamente na lei. Isto pode acontecer também quando um membro de uma organização criminosa, por qualquer motivo, resolva confessar e colaborar com a investigação, quando da lavratura do seu próprio flagrante (unilateral, por conseguinte). Evidentemente, que aí o colaborador não terá a certeza de que o juiz lhe concederá um daqueles 'prêmios', o que tornará rara a hipótese. Por outro lado, neste caso, o Ministério Público pode deixar de denunciá-lo (arquivamento do inquérito) ou requerer o perdão a qualquer momento, (como custos legis, que pode até opinar pela absolvição), que será concedido ou não na sentença final". ${ }^{60}$

59 MASSON, Cleber e MARÇAL, Vinícius. Ob. cit., p. 100-101.

60 JARDIM, Afrânio Silva. Nova Interpretação Sistemática do Acordo de Cooperação Premiada. ESPIÑEIRA, Bruno, CALDEIRA, Felipe (orgs.). 
Premiar a colaboração unilateral significa evitar a seletividade em torno da aplicação do instituto, quer do ponto de vista político, quer sob o enfoque social e econômico. A cooperação, tal qual contemplada na Lei $\mathrm{n}^{\circ} 12.850 / 13$, volta-se para as persecuções penais de vulto, de intensa visibilidade, com repercussão, no mínimo, municipal - e a denominada Operação Lavajato, acionando $n$ pactos de colaboração, é exemplo disso. As rodadas intermináveis de negociação e de depoimentos, imprescindíveis à celebração do pacto, mobilizam não todo e qualquer imputado, mas apenas aquele em condições de suportá-las, perpassando, obviamente, pela contratação de advogados, afinal são causas que exigem (quase) dedicação exclusiva. Tal quadra foge da realidade, por exemplo, das Defensorias Públicas, cujos integrantes, em geral, ficam vinculados a determinado(s) Juízo(s), oficiando nos processos em curso no(s) citado(s) órgão(s), a maioria, aliás, está sob os seus auspícios.

A capilaridade da Defensoria Pública, ainda em processo de implementação e de expansão em muitos Estados, e, mesmo, em nível federal, é outro entrave à "democratização" do instituto, na modalidade de "acordo bilateral" idealizada pela Lei no 12.850/13. Embora o art. $5^{\circ}$, LXIII, da Carta de 1988 preconize o direito dos indiciados à assistência jurídica, tendo a Lei Complementar $n^{0} 132$, de 7 de outubro de 2009, incluído no art. $4^{\circ}$ da Lei Complementar 80, de 12 de janeiro de 1994, o inciso VIII, para assentar ser função institucional da Defensoria "acompanhar inquérito policial, inclusive com a comunicação imediata da prisão em flagrante pela autoridade policial, quando o preso não constituir advogado", a atuação direta dá-se perante o Juízo, considerado o recebimento de cópia do auto de prisão em flagrante e eventual pedido de relaxamento da prisão ou de liberdade provisória, ex vi do art. $306, \S 1^{\circ} \mathrm{c} / \mathrm{c}$ art. 310 do $\mathrm{CPP}$, quando não realizada a audiência de custódia, voltada, fundamentalmente, à aferição de eventual cometimento de tortura ou de maus tratos contra o capturado e ao exame da legalidade e/ou necessidade da custódia, tanto que a Resolução no 213 do Conselho Nacional de Justiça (CNJ), ao discipliná-la, preconizou, no art. $8^{\circ}$, VIII, dever o magistrado "abster-se de formular perguntas com finalidade de produzir prova para a investigação ou ação penal relativas

Delação Premiada, ob. cit., p. 37-39. 
aos fatos objeto do auto de prisão em flagrante”. Não há espaço, portanto, para tratativas em torno de uma potencial cooperação.

A ausência da Defensoria Pública em acordos de colaboração premiada já foi identificada por Rubens Casara e Antonio Pedro Melchior ${ }^{61}$. Imagine, v.g., uma operação policial a resultar na apreensão de $100 \mathrm{~kg}$ de cocaína, depositada em um armazém. Entre os capturados em flagrante, um indica outros 2 galpões nos quais haveria material entorpecente estocado, vindo a Polícia a arrecadar mais 200kg de cocaína e a prender mais 4 infratores, além do gerente do tráfico. Tais informações culminaram na identificação e captura de outros coautores e na recuperação parcial do produto do crime, concretizando 2 dos resultados delineados no art. $4^{\circ}$, incisos I e IV, da Lei n ${ }^{\circ} 12.850 / 13$. Não há como negar a esse imputado o prêmio, nada obstante a ausência de acordo formalizado, em prol de uma reles atenuante genérica - confissão, versada no art. 65, III, d do Código Penal -, sob pena de legitimar uma postura contra legem.

A premiação poderá ser buscada pela Defesa por meio de requerimento dirigido ao Juízo, inclusive em sede de alegações finais, ouvido o Ministério Público, cujo parecer, todavia, não vincularia aquele, afinal perdão judicial e aplicação da pena são matérias com reserva de jurisdição. Caso a cooperação fosse acenada pelo acusado durante o processo, nada impediria à Defesa peticionar ao juiz esclarecendo dispor o imputado de informações reveladoras dos locais de armazenamento da droga e, portanto, de atuação de outros traficantes, pedindo à autoridade judiciária processante determinada premiação caso os dados, uma vez disponibilizados pelo denunciado, atingissem os resultados listados na norma. A homologação judicial da proposta dar-se-ia bilateralmente, se o parecer do Parquet fosse positivo, ou unilateralmente, se contrário.

Alexandre de Castro Coura e Américo Bedê Junior até contemplam um controle jurisdicional sobre a colaboração premiada, mas restrito às hipóteses de impedimento ou de suspeição do promotor contrário ao acordo, deixando a aferição a cargo do sucessor. Admitem, por

61 CASARA, Rubens; MELCHIOR, Antonio P. Estado Pós-Democrático e Delação Premiada: Crítica ao Funcionamento Concreto da Justiça Criminal Negocial no Brasil. In: ESPIÑEIRA, Bruno; CALDEIRA, Felipe (Org.). Delação Premiada, ob. cit., p. 427, nota 26. 
outro lado, o alargamento da premiação pelo juiz, mas não a redução, sob pena de ofensa ao princípio da confiança ${ }^{62}$.

Propostas como essa, ou a aplicação, por analogia, do art. 28 do CPP, persistem em dar ao Ministério Público a última palavra a respeito de questões absolutamente sujeitas à reserva de jurisdição, como declaração de extinção da punibilidade (perdão judicial) e fixação da reprimenda, em descompasso com o art. $2^{\circ}$ da Constituição - o Parquet imiscuir-se-ia em esfera estritamente jurisdicional. Vicente Greco Filho, debruçando-se sobre a colaboração premiada prevista no art. 41 da Lei $n^{\circ} 11.343 / 06$, já lecionava que os órgãos de repressão estatal podem atestar “(...) a ocorrência das circunstâncias que entenderem cabíveis, ou não, para a aplicação do benefício, que o juiz apreciará livremente ao proferir sentença" ${ }^{63}$. Não há como ser diferente, lembrando que, na Itália, o patteggiamento desafia deferimento pelo Juízo, a pedido da defesa, mesmo ante o parecer contrário do Ministério Público. Entregar ao Parquet a deliberação final apenas se justifica quando o prêmio corresponder ao não oferecimento da denúncia, por ser a ação penal pública privativa sua, o que explica a menção ao art. 28 do CPP no $\$ 2^{\circ}$ do art. $4^{\circ}$ da Lei $n^{\circ} 12.850 / 13$.

Como as declarações do colaborador unilateral estariam documentadas nos autos, quer na confissão do imputado, quer subsequentemente ao pedido defensivo, bem como o pronunciamento jurisdicional homologatório da cooperação ou de deferimento, ou não, da premiação, podendo o último vir na própria sentença, a publicidade do processo ficaria preservada.

Partindo-se desse cenário, a hipotética celebração do acordo entre a autoridade policial e o indiciado, ainda no inquérito, nada teria de inconstitucional. Primeiramente, porque o foco imediato seria a efetividade e a eficiência da investigação, cuja condução é privativa dos delegados por mandamento constitucional - art. $144, \S \S 1^{\circ}$, IV e $4^{\circ}$ da Lei Maior -, potencializado pelo art. $2^{\circ}$ da Lei $\mathrm{n}^{\circ} 12.830$, de 20 de junho de

62 COURA, Alexandre C.; BEDÊ JR., Américo. Atuação do Juiz em face de Acordos de Colaboração Premiada. In: ESPIÑEIRA, Bruno; CALDEIRA, Felipe (Org.). Delação Premiada, ob. cit., p. 65-68.

63 GRECO FILHO, Vicente. Tóxicos. $14^{\mathrm{a}}$ edição. São Paulo: Saraiva, 2011, p.242. 
2013, notadamente os $\S \S 1^{\circ}$ e $6^{\circ}$, conforme bem observado por Márcio Adriano Anselmo ${ }^{64}$, Francisco Sannini Neto e Henrique Hoffmann ${ }^{65}$. O encaminhamento do pacto à chancela jurisdicional não alçaria a autoridade policial à posição de sujeito processual, mesmo porque encampada pelo imputado e seu defensor, esses, sim, atores do processo, não tendo o delegado qualquer influência na concessão, ou não, do prêmio. Se obtidos os resultados previstos em lei, em decorrência das informações disponibilizadas, o prêmio é consequência legal, restando ao juiz implementá-la. A autoridade policial continua estranha ao processo. Cientificar o Ministério Público a respeito da avença, colhendo o parecer, basta à preservação do sistema acusatório, respeitando-se a titularidade privativa da ação penal pública, a ele confiada pelo Poder Constituinte Originário, ex vi do art. 129, I, mesmo porque o magistrado atuaria a partir da provocação defensiva, e não ex officio. Ademais, em sendo os critérios para a outorga da benesse legais, independe da opinião ministerial, podendo o juiz deferi-la, mesmo se contrário o parecer, afinal em jogo estão a extinção da punibilidade e/ou a aplicação da pena, questões de enfrentamento obrigatório pelo magistrado, porque sujeitas à reserva de jurisdição. Não se discute o oferecimento da denúncia ou o seu prosseguimento, presentes a transação e a suspensão condicional do processo, respectivamente, essas, sim, de atribuição privativa do Parquet, por refletirem na obrigatoriedade ou na indisponibilidade da ação penal pública.

\section{Considerações finaIS}

1. Desde que as informações disponibilizadas, unilateralmente, pelo colaborador atinjam os resultados previstos em lei para a pre-

\footnotetext{
64 ANSELMO, Márcio Adriano. Legitimidade do Delegado de Polícia para Celebrar Colaboração Premiada. In: HOFFMAN, Henrique, MACHADO, Leonardo Marcondes, GOMES, Rodrigo Carneiro, ANSELMO, Márcio Adriano, BARBOSA, Ruchester Marreiros. Investigação Criminal pela Polícia Judiciária. Rio de Janeiro, Lumen Juris, 2016, p. 121-122.

65 SANINI NETO, Francisco; HOFFMANN, Henrique. Delegado de Polícia tem Legitimidade para Celebrar Colaboração Premiada. Disponível em: <http:// www.conjur.com.br/2016-mar-04/delegado-legitimidade-celebrar-colaboracao-premiada>. Acesso em: 7 fev. 2017.
} 
miação, faz-se mister a concessão do prêmio pelo juiz, independentemente da existência de qualquer acordo previamente firmado com o Ministério Público. Tal constatação é decorrência natural dos postulados constitucionais do devido processo legal, da separação entre os Poderes da República, da ampla defesa e da razoabilidade, sob o ângulo da proporcionalidade.

2. O único prêmio, pertinente à cooperação prestada pelo imputado, submetido à iniciativa privativa do Ministério Público, sem controle maior do Judiciário, consiste no não oferecimento da denúncia, previsto no $\S 4^{\circ}$ do artigo $4^{\circ}$ da Lei $n^{\circ} 12.850 / 2013$. Vislumbrando ser caso de futuro perdão judicial, cuja natureza é meramente declaratória, extinguindo-se a punibilidade a partir do momento em que as informações prestadas pelo colaborador conduzem aos resultados previstos em lei, nos moldes do Enunciado $\mathrm{n}^{0} 18$ de Súmula do STJ ${ }^{66}$, o Parquet, por falta de interesse de agir (utilidade), promove o arquivamento. Dissentindo o juiz, remete os autos à Procuradoria-Geral de Justiça, no âmbito do Ministério Público Estadual, ou à Segunda Câmara de Coordenação e Revisão, no universo do Ministério Público Federal, nos termos do artigo 28 do Código de Processo Penal, sendo este o real alcance do $\S 2^{\circ}$ do citado artigo $4^{\circ}$. Evocar a colaboração como fundamento para o arquivamento incumbe, unicamente, ao Parquet, enquanto titular privativo da ação penal (artigo 129, I, da Constituição). Merece descarte, todavia, o entendimento segundo o qual existiria, nesse caso, um acordo de imunidade, revelador de causa sui generis de extinção da punibilidade. Criar-se-ia causa extintiva da punibilidade à margem de previsão legal, em desacordo com o princípio da legalidade penal estrita. Invocar-se-ia institutos próprios ao plea bargaining, no caso immunity, sem previsão nem delineamento no ordenamento processual penal pátrio, em dissonância com a cláusula do devido processo legal (art. $5^{\circ}$, LIV, da Constituição). Finalmente, em sendo do Ministério Público a palavra final acerca do oferecimento, ou não, da denúncia, extinção da punibilidade não há, afinal a sua formalização é matéria reserva de jurisdição, competindo ao juiz.

66 "A sentença concessiva do perdão judicial é declaratória da extinção da punibilidade, não subsistindo qualquer efeito condenatório". 
3. Admitindo-se premiar a colaboração unilateral, a cooperação obtida, diretamente, pela autoridade policial mostra-se constitucional. Além de a participação do Ministério Público ser prescindível à concessão dos benefícios correspondentes à cooperação, o delegado a fim de elucidar o fato em apuração, colhendo evidências que abasteçam a investigação, que tem nele o seu presidente e condutor, considerado o artigo $144, \S \S 1^{\circ}$, IV e $4^{\circ}$, da Constituição, reforçado pelo artigo $2^{\circ}, \S \S 1^{\circ}$ e $6^{\circ}$ da Lei ${ }^{\circ} 12.830$, de 20 de junho de 2013. Como o Parquet tomará ciência de todo o apurado, para, então, manifestar-se, ex vi dos $\S \S 2^{\circ} \mathrm{e}$ $6^{\circ}$ do artigo $4^{\circ}$ da Lei $n^{\circ} 12.850 / 13$, não se usurpa a titularidade da ação penal, que lhe é privativa, preservando-se o inciso I do artigo 129 da Carta de 1988.

4. Partindo-se da premissa, segundo a qual a premiação independe de acordo prévio, sob pena de permitir ao Ministério Público, parte autora, intervir no conteúdo da prestação jurisdicional, em manifesta afronta ao artigo $2^{\circ}$ da Constituição, reconhece-se, por coerência científica, que a homologação do pacto confere ao colaborador o direito público subjetivo ao prêmio, se confirmadas as informações transmitidas. Mas as benesses serão definidas pelo juiz quando da prolação da sentença, afinal as partes não podem interferir no julgamento, sob pena de se privatizar a justiça penal. Conforme preconiza o artigo $4^{\circ}, \S 7^{\circ}$, da Lei $n^{\circ} 12.850 / 13$, a chancela jurisdicional avaliza a regularidade, a legalidade e a voluntariedade da avença, buscando vícios formais ou na manifestação da vontade, sem adentrarno mérito, o que inclui a adequação ou não do benefício, considerado o princípio da suficiência da pena. Se os fatos delituosos que a ensejaram ainda não foram apurados em processo judicial, nem ratificadas as informações prestadas, como poderia o juiz avaliar a pertinência das benesses? Tal incursão intelectiva há de ser feita na sentença, segundo disposto no $§ 11$ do artigo $4^{\circ}$. Embora o Supremo tenha assinalado o contrário, quando do julgamento do $\mathrm{HC} \mathrm{n}^{\mathrm{o}} 127.483 / \mathrm{PR}$, a impetração não gravitou sobre esse tema, porque formalizada por corréu a fim de nulificar a decisão homologatória de acordo de colaboração premiada. Tais considerações tiveram dimensão obiter dictum (argumento de reforço), sem configurar a ratio decidendi. 


\section{REFERÊNCIAS BIBLIOGRÁFICAS}

ALKON, Cynthia, Plea Bargaining as a Legal Transplant: A Good Idea for Troubled Criminal Justice Systems? Transnational Law and Contemporary Problems, v. 19, p. 355-418, abr./2010.

ANSELMO, Márcio Adriano, Legitimidade do Delegado de Polícia para Celebrar Colaboração Premiada. In: HOFFMAN, Henrique; MACHADO, Leonardo M.; GOMES, Rodrigo C.; ANSELMO, Márcio A.; BARBOSA, Ruchester M. Investigação Criminal pela Polícia Judiciária. Rio de Janeiro: Lumen Juris, 2016, p. 116-122.

BANDEIRA DE MELLO, Celso Antônio. Curso de Direito Administrativo. 16 ${ }^{\mathrm{a}}$ edição, São Paulo: Malheiros, 2003.

BATISTA, Weber Martins; FUX, Luiz. Juizados Especiais Cíveis e Criminais e Suspensão Condicional do Processo Penal. Rio de Janeiro: Forense, 1998.

CASARA, Rubens R. R.; MELCHIOR, Antonio P. Estado Pós-Democrático e Delação Premiada: Crítica ao Funcionamento Concreto da Justiça Criminal Negocial no Brasil. In: ESPIÑEIRA, Bruno; CALDEIRA, Felipe (Org.). Delação Premiada. Belo Horizonte: D’Plácido, 2016. p. 411-443.

CONSO, Giovanni; GREVI, Vittorio. Codice di Procedura Penale e Norme Complementari. Milão: Giuffrè, 2001.

COURA, Alexandre de Castro, BEDÊ JUNIOR, Américo. Atuação do Juiz em face de Acordos de Colaboração Premiada. In: ESPIÑEIRA, Bruno; CALDEIRA, Felipe (Org.). Delação Premiada. Belo Horizonte: D’Plácido, 2016, p. 63-74.

COUTINHO, Jacinto; CARVALHO, Edward Rocha de. Acordos de delação premiada e o conteúdo ético mínimo do Estado. Revista de Estudos Criminais, São Paulo, ano VI, n. 22, p. 75-84, abr./jun. 2006.

DERWAN, Lucian E., EDKINS, Vanessa A. Edkins. The Innocent Defendant's Dilemma: An Innovative Empirical Study of Plea Bargaining's Innocence Problem. Journal of Criminal Law and Criminology, v. 103, n. 1, p. 01-48, mai./2012.

DIPP, Gilson. A “delação” ou colaboração premiada: uma análise do instituto pela interpretação da lei. Brasília: IDP, 2015. http://dx.doi.org/10.11117/9788565604574 FERRAJOLI, Luigi. Direito e Razão. Teoria do Garantismo Penal. São Paulo: RT, 2002.

FILIPPETTO, Rogério, ROCHA, Luísa Carolina Vasconcelos Chagas. Colaboração Premiada: Contornos segundo o Sistema Acusatório. Belo Horizonte: D’Plácido, 2017. 
GRECO FILHO, Vicente. Tóxicos: Prevenção e Repressão. 14a edição. São Paulo,: Saraiva, 2011.

GRINOVER, Ada Pellegrini Grinover et al.. Juizados Especiais Criminais. $4^{\mathrm{a}}$ ed. São Paulo: RT, 2002.

HOFFMANN, Henrique, SANNINI NETO, Francisco, Delegado de Polícia tem Legitimidade para Celebrar Colaboração Premiada. Disponível em <http://www. conjur.com.br/2016-mar-04/delegado-legitimidade-celebrar-colaboracaopremiada >. Acesso em: 06 fev. 2017.

HESSIK, Andrew, SAUJANI, Reshma, Plea Bargaining and Convicting the Innocent: the Role of the Prosecutor, the Defense Counsel and the Judge. Bringham Young University Journal of Public Law, v.16, pp.189-242, 2002.

JARDIM, Afrânio Silva. Nova Interpretação Sistemática do Acordo de Cooperação Premiada. In: ESPIÑEIRA, Bruno; CALDEIRA, Felipe (Org.). Delação Premiada. Belo Horizonte: D'Plácido, 2016, p. 33-40. Disponível em: http://emporiododireito.com.br/nova-interpretacao-sistematica-do-acordode-cooperacao-premiada-por-afranio-silva-jardim/>. Acesso em: 11 jan. 2016.

JESUS, Damásio E. de. Lei dos Juizados Especiais Criminais Anotada. $7^{a}$ ed. São Paulo: Saraiva, 2002.

MASSON, Cleber e MARÇAL, Vinícius. Crime Organizado. São Paulo: Método, 2015.

MENDONÇA, Andrey Borges de. A colaboração premiada e a nova Lei do Crime Organizado (Lei 12.850/2013). Custos legis - Revista Eletrônica do Ministério Público Federal, vol. 4, 2013.

MORELLO, Michele. Il Nuovo Processo Penale, parte generale. Padova: CEDAM, 2000.

MUSSO, Rosanna Gambini. Il Processo Penale Statunitense, Soggetti ed Atti. $2^{\mathrm{a}}$ ed., Torino: G. Giappichelli, 2001.

NICOLITT, André. Juizados Especiais Criminais, Temas Controvertidos. Rio de Janeiro: Lumen Juris, 2002.

OLIVEIRA, Eugênio Pacelli de. Curso de Processo Penal. 19ª ed. São Paulo: Atlas, 2015.

PEREIRA, Frederico Valdez, O Procedimento da Colaboração Premiada e as Inovações da Lei n ${ }^{0}$ 12.850/13. In: ZANOTTI, Bruno Taufner, SANTOS, Cleopas Isaías (org.) Temas Atuais de Polícia Judiciária, $2^{\mathrm{a}}$ edição, Salvador, Jus Podivm, 2016, p. 331-345. 
PERRODET, Antoinette. "Il processo penale in Itália". In: DELMAS-MARTY, Mireille; CHIAVARIO, Mario (Org.). Procedure Penali D’Europa. $2^{\text {a }}$ ed., Padova: CEDAM, 2001.

PINHO, Humberto Dalla Bernardina de, PORTO, José Roberto Sotero de Mello. Colaboração Premiada: Um Negócio Jurídico Processual? In: ESPIÑEIRA, Bruno; CALDEIRA, Felipe (Org.). Delação Premiada. Belo Horizonte: D’Plácido, 2016, p. 115-143.

PRADO, Geraldo e CARVALHO, Luis Gustavo Grandinetti Castanho de. Lei dos Juizados Especiais Criminais, Comentários e Anotações. $3^{\text {a }}$ ed., Rio de Janeiro: Lumen Juris, 2003.

PRADO, Geraldo, Elementos para uma Análise Crítica da Transação Penal, Rio de Janeiro, Lumen Juris, 2003.

Saltzburg, Stephen A; Capra, Daniel. J. American Criminal Procedure, Cases and Commentary. $5^{a}$ ed. St. Paul, Minn.: American Casebook Series, West Publishing Co., 1996.

SANTOS, Marcos Paulo Dutra. Colaboração (Delação) Premiada. Salvador: Jus Podivum, 2016.

SANTOS, Marcos Paulo Dutra. Transação Penal. Rio de Janeiro: Lumen Juris, 2006.

SENNA, Gustavo, BEDÊ JUNIOR, Américo, A Colaboração Premiada no Brasil. In: ZANOTTI, Bruno Taufner, SANTOS, Cleopas Isaías (org.). Temas Atuais de Polícia Judiciária, $2^{a}$ edição, Salvador, Jus Podivm, 2016, p. 347-390.

SILVA, Eduardo Araújo da. Organizações Criminosas, Aspectos Penais e Processuais da Lei no 12.850/13. $2^{\text {a }}$ ed. São Paulo: Atlas, 2015.

TOURINHO FILHO, Fernando da Costa. Comentários à Lei dos Juizados Especiais Criminais. São Paulo: Saraiva, 2000.

TOURINHO NETO, Fernando da Costa. Delação Premiada, Colaboração Premiada, Traição Premiada Endurecimento das Decisões Judiciais. Afronta à Constituição Federal. Juiz Justiceiro. In: ESPIÑEIRA, Bruno; CALDEIRA, Felipe (Org.). Delação Premiada. Belo Horizonte: D’Plácido, 2016, p. 499-525.

TULKENS, Françoise. Una Giustizia Negoziata?, Il processo penale in Itália. In: DELMAS-MARTY, Mireille; CHIAVARIO, Mario (Org.). Procedure Penali D'Europa. $2^{\text {a }}$ ed., Padova: CEDAM, 2001.

VASCONCELLOS, Vinicius G. Barganha e Justiça Criminal Negocial, Análise das Tendências de Expansão dos Espaços de Consenso no Processo Penal Brasileiro. São Paulo: IBCCRIM, 2015. 
VASCONCELLOS, Vinicius G.; CAPPARELLI, Bruna. Barganha no Processo Penal Italiano: Análise Crítica do Patteggiamento e das Alternativas Procedimentais na Justiça Criminal. Revista Eletrônica de Direito Processual - REDP, vol. 15, p. 435453, jan./jun. 2015. http://dx.doi.org/10.12957/redp.2015.16880

WHITEBREAD, Charles H. e SLOBOGIN, Christopher. Criminal Procedure, An Analysis of Cases and Concepts. $4^{\mathrm{a}}$ ed. Nova Iorque: University Textbook Series, Foundation Press, 2000.

Dados do processo editorial

(http://www.ibraspp.com.br/revista/index.php/RBDPP/about/editorialPolicies)

- Recebido em: 08/01/2017

Equipe editorial envolvida

- Controle preliminar e verificação de plágio: 08/01/2017

- Avaliação 1: 18/01/2017

- Avaliação 2: 19/01/2017

- Avaliação 3: 24/01/2017

- Editor-chefe: 1 (VGV)

- Editora-associada: 1 (SRM)

- Editora-assistente: 1 (BC)

- Revisores: 3

- Decisão editorial preliminar: 26/01/2017

- Retorno rodada de correções: 08/02/2017

- Decisão editorial final: 08/02/2017

\section{COMO CITAR ESTE ARTIGO:}

SANTOS, Marcos P. D. Colaboração unilateral premiada como consectário lógico das balizas constitucionais do devido processo legal brasileiro. Revista Brasileira de Direito Processual Penal, Porto Alegre, vol. 3, n. 1, p. 131-166, jan./abr. 2017. https://doi.org/10.22197/rbdpp.v3i1.49

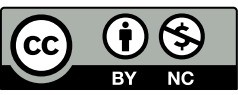

Esta obra está licenciada com uma Licença Creative Commons Atribuição-NãoComercial 4.0 Internacional. 